\title{
Situational diagnosis of medication use among the elderly attended at public pharmacies in the city of Veranópolis/RS
}

\begin{abstract}
Objective: To identify the medical and sociodemographic profile and interest in accessing the clinical pharmaceutical services of elderly polymedicated individuals who use public pharmacies in Veranópolis, RS, Brazil, as well as to evaluate their adherence to drug treatment, comparing it among units where there is a pharmacist or not. Methods: A cross-sectional study with 141 patients. A structured questionnaire with sociodemographic and health questions and the Portuguese version of the Brief Medication Questionnaire to analyze the adherence to treatment were used. Results: Of the respondents, $65.2 \%$ were female, $46.1 \%$ were between $70-79$ years old, $90.1 \%$ white, $63.1 \%$ married, $88.7 \%$ retired, $55.3 \%$ had incomplete elementary school and $80.9 \%$ earned one or two minimal salaries monthly. A total of $58.2 \%$ interviewed individuals said that they had never smoked, $68.8 \%$ used public and private pharmacies to obtain their medicines and $58.2 \%$ practiced self-medication. About the pharmaceutical services, $66.7 \%$ of the elderly did not know and $85.8 \%$ showed interest in receiving these services. There was a prevalence of cardiovascular diseases $(94.3 \%)$ and the most prescribed medication was simvastatin, used by $56.0 \%$ of the patients. The adherence to treatment classified them as probable adherence $(9.2 \%)$, probable low adherence (46.8\%) and low adherence (44.0\%). The variable "presence of the pharmacist in the pharmacy" did not show a significant association $(\mathrm{p}<0.05)$ with adherence. Conclusion: Most of the elderly do not adhere to treatment properly and use potentially inappropriate medications, showing the need to improve pharmaceutical care promoting a rational use of medicines
\end{abstract}

Keywords: Elderly. Polypharmacy. Adherence to treatment. Cross-sectional studies. Pharmaceutical services.

\section{Diagnóstico situacional do uso de medicamentos em idosos} atendidos nas farmácias públicas do município de Veranópolis/RS

\section{Resumo}

Objetivo: Identificar o perfil medicamentoso, sociodemográfico e o interesse em acessar os serviços farmacêuticos clínicos de idosos polimedicados que utilizam as farmácias públicas do município de Veranópolis, RS, Brasil, bem como avaliar a adesão ao tratamento medicamentoso, comparando-a entre unidades onde há ou não a presença do farmacêutico. Métodos: Estudo transversal com 141 pacientes. Os dados foram coletados por meio de questionário sociodemográfico e relacionado a saúde e através da versão validada em português do Brief Medication Questionnaire para análise da adesão. Resultados: Entre os respondentes, $65,2 \%$ eram do sexo feminino, 46,1\% entre $70-79$ anos, $90,1 \%$ da cor branca, $63,1 \%$ casados, $88,7 \%$ aposentados, $55,3 \%$ com ensino fundamental incompleto e $80,9 \%$ com renda mensal de um a dois salários mínimos. Um total de $58,2 \%$ dos entrevistados relatou nunca ter fumado, $68,8 \%$ utilizavam o sistema público e a rede privada para obter seus medicamentos e $58,2 \%$ praticavam a automedicação. A respeito dos serviços farmacêuticos, $66,7 \%$ dos idosos disseram não conhecer e $85,8 \%$ demonstraram interesse em recebê-los. Houve prevalência das doenças cardiovasculares (94,3\%) e o medicamento mais encontrado nas prescrições foi a sinvastatina, utilizada por $56,0 \%$ dos pacientes. A análise da adesão classificou-os em provável adesão (9,2\%), provável baixa adesão (46,8\%) e baixa adesão (44,0\%). A variável presença do farmacêutico na unidade não apresentou associação significativa $(p<0,05)$ com a adesão. Conclusão: A maioria dos idosos não adere adequadamente ao tratamento e utiliza medicamentos potencialmente inapropriados, destacando a necessidade de aprimoramento da assistência farmacêutica buscando o uso racional de medicamentos.

Palavras-chave: Idosos. Polifarmácia. Adesão ao tratamento. Estudos transversais. Serviços farmacêuticos.
1 Universidade de Caxias do Sul 2 Secretaria da Saúde, Veranópolis, RS, Brasil

Submitted: $12 / 07 / 18$

Resubmitted: 24/07/19

Aceptted: 05/09/19

DOI: $10.30968 /$ rbfhss.2019.103.0325

ISSN online: $2316-7750$

Corresponding Author:

Carla Rigon

crigon@ucs.br 


\section{Introduction}

The World Health Organization (WHO) defines the elderly chronologically as being aged 65 or older in developed countries, and 60 or older in developing countries. ${ }^{1}$ Longevity, once considered a phenomenon, is now part of society. In Brazil, the demographic and epidemiological transition has been occurring since the 1970s. The elderly population of 20 million in 2010 is expected to exceed 65 million by $2050{ }^{2}$

As the number of elderly individuals is increasing, the consumption of medications by this population also grows considerably. The prevalence of chronic noncommunicable diseases (CNCDs) with increasing age implies high drug consumption. In the country, CNCDs grow at a fast pace, becoming a priority in the development of health actions. Pharmacotherapy represents one of the most important aspects in health care for the elderly, since drugs behave differently in the body of the elderly due to physiological, pharmacokinetic and pharmacodynamic changes. These changes can be more critically evident in polymedicated elderly individuals who use five or more drugs continuously, and this group is more vulnerable to inappropriate drug use. ${ }^{2}$

Knowledge of the drug use profile by the geriatric population is fundamental for the design of strategies to achieve a rational drug use, and pharmaceutical monitoring would facilitate this process. ${ }^{3,4}$ Among the factors that directly influence the therapeutic results, adherence to treatment stands out, defined as the degree of agreement between the patient's behavior and the guidance provided by the health professional. Non-adherence to treatment is considered a public health problem and also a multi-factorial phenomenon.

The municipality of Veranópolis is located in the northeast of the state of Rio Grande do Sul, 170 kilometers from the capital, Porto Alegre. Veranópolis is known as the "Land of Longevity" and recently received the title granted by the WHO of Friendly City of the Elderly. According to data from the last demographic census (2010), the population of Veranópolis was 22,810 inhabitants. Of these, 3,493 were 60 years old or older, with 1,974 women $(56.5 \%)$ and 1,519 men (43.5\%), representing $15.3 \%$ of the individuals. ${ }^{6}$

Since 1994, the city has developed actions aimed at aging with quality of life through the Veranópolis Project. The longevity of this municipality is highlighted nationally and internationally through several works already published. Despite the studies available, there are no studies evaluating the profile of the elderly assisted in public health in this city of Rio Grande do Sul.

Therefore, the present study aimed to analyze the profile of medication use in elderly patients seen at the Veranópolis public pharmacies, as well as to outline their sociodemographic profile, to identify the most prevalent diseases, to evaluate adherence to drug treatment and to compare it among units with or without a pharmaceutical professional present, and to determine the interest of the patients in accessing clinical pharmaceutical services.

\section{Methods}

\section{Design of the study}

This is a cross-sectional, descriptive and quantitative study.

\section{Study site}

The research was conducted in the Public Pharmacies of Veranópolis, RS, Brazil, in the second half of 2017. The data collected at the Central Pharmacy, an establishment where there is a pharmaceutical professional, and in four Family Health Strategy (FHS) pharmacies: Medianeira, São Francisco, Santo Antônio and Renovação.

\section{Inclusion criteria}

Elderly patients aged 60 years old or older who were on polypharmacy and who withdrew at least one of their continuous-use drugs from the public pharmacies were selected. Only those who personally withdrew their medications and who agreed to participate in the study after reading, understanding and signing the Free and Informed Consent Form were considered.

\section{Exclusion criteria}

Patients were excluded who had their drugs withdrawn by third parties, under 60 years of age, with total dependence, and individuals over 60 years old, but who did not use five or more drugs.

\section{Sampling}

The sample $(\mathrm{n}=384)$ was calculated by estimating a proportion, considering the WHO's non-adherence rate of approximately $50 \%$ for chronic treatments. $^{8}$ The municipality of Veranópolis has around $50 \%$ of its territory covered by the FHS. Due to the greater flow of patients seen at the Central Pharmacy when compared to the other units, the sample size was divided into two equal parts, with half of the respondents approached in the aforementioned establishment and the other portion divided among the remaining units.

\section{Data collection and storage}

The questionnaires were administered by three properly trained interviewers, one pharmacy scholar and two pharmacists. The patients in the study were identified at the time of the pharmacy service by the attendants and invited to participate in the research. If they accepted, the interviews were scheduled or held at the same time in a private room. In the FHS units, interviews were scheduled by nurses or health agents and researchers went to the units to apply the questionnaires.

The sociodemographic information collected was gender, age, skin color, marital status, schooling level, retirement, individual monthly income, housing and caregiver presence. The health-related data included smoking, selfmedication, disease history, place for obtaining medications, prior knowledge of pharmaceutical services, and subsequent interest in receiving them. Medication adherence was assessed using the validated Portuguese version of the Brief Medication Questionnaire (BMQ) with eleven questions. Drug information was obtained from the prescriptions presented by the patients. The score of problems encountered by the BMQ in each domain (regimen, beliefs and recall) was obtained by comparing the patients' responses with the prescriptions received, adding a point to each affirmative answer. The BMQ classification was categorized into four outcomes: adherence (no positive response), probable adherence (positive response in one domain), probable low adherence (positive response in two domains) and low adherence (positive response in three domains). 9

\section{Analysis and interpretation of the collected data}

The analyses were conducted in the Statistical Package for the Social Sciences (SPSS) version 14.0 and in Microsoft Excel 2016. The continuous variables were presented as mean value and standard deviation, while categorical ones, as frequency and percentage. The comparison of the adherence to treatment of the elderly attended at the Central Public Pharmacy, where there is a pharmacist, with the elderly who purchase their drugs in the FHS was performed using the Pearson's chi-square test to assess the statistical significance of the differences between the groups, considering the significance level of $5 \%$. For this specific analysis, the elderly belonging to the "low adherence" and "probable low adherence" groups were classified as non-adherent versus the "probable adherence" group.

\section{Ethical aspects}

The research project was submitted to the Ethics and Research Committee of the University of Caxias do Sul, and was approved under opinion No. 2,261,197.

\section{Results}

Table 1 presents the sociodemographic profile and health indicators reported by the 141 elderly individuals interviewed. The mean age among the respondents was $70.7 \pm 6.6$ years old. 
Table 1. Sociodemographic variables and health indicators.

\begin{tabular}{|c|c|}
\hline Variables & n $(\%)$ \\
\hline \multicolumn{2}{|l|}{ Gender } \\
\hline Female & $92(65.2)$ \\
\hline Male & $49(34.8)$ \\
\hline \multicolumn{2}{|l|}{ Age } \\
\hline 60 to 69 years old & $60(42.6)$ \\
\hline 70 to 79 years old & $65(46.1)$ \\
\hline 80 to 89 years old & $16(11.3)$ \\
\hline \multicolumn{2}{|l|}{ Marital status } \\
\hline Married & $89(63.1)$ \\
\hline Widower & $38(27.0)$ \\
\hline Single & $4(2.8)$ \\
\hline Separated & $9(6.4)$ \\
\hline Other & $1(0.7)$ \\
\hline \multicolumn{2}{|l|}{ Skin color } \\
\hline Caucasian & $127(90.1)$ \\
\hline Black & $9(6.4)$ \\
\hline Brown-skinned & $4(2.8)$ \\
\hline Asian & $1(0.7)$ \\
\hline \multicolumn{2}{|l|}{ Schooling level } \\
\hline Not literate & $10(7.1)$ \\
\hline Elementary school incomplete & $78(55.3)$ \\
\hline Fundamental level & $41(29.1)$ \\
\hline Middle level & $10(7.1)$ \\
\hline College degree & $2(1.4)$ \\
\hline \multicolumn{2}{|l|}{ Lives with } \\
\hline Alone & $20(14.2)$ \\
\hline Husband/Wife & $85(60.3)$ \\
\hline Children & $30(21.3)$ \\
\hline Grandchildren & $2(1.4)$ \\
\hline Other & $4(2.8)$ \\
\hline \multicolumn{2}{|l|}{ Retirement } \\
\hline Yes & $125(88.7)$ \\
\hline No & $16(11.3)$ \\
\hline \multicolumn{2}{|l|}{ Individual monthly income } \\
\hline$<1$ minimum wage & $8(5.7)$ \\
\hline 1 to 2 minimum wages & $114(80.9)$ \\
\hline 3 to 4 minimum wages & $8(5.7)$ \\
\hline 5 to 6 minimum wages & $2(1.4)$ \\
\hline Has no income & $9(6.4)$ \\
\hline \multicolumn{2}{|l|}{ Caregiver } \\
\hline Yes & $41(29.1)$ \\
\hline No & $100(70.9)$ \\
\hline \multicolumn{2}{|l|}{ Smoking } \\
\hline Never smoked & $82(58.2)$ \\
\hline Ex smoker & $52(36.9)$ \\
\hline Current smoker & $7(5.0)$ \\
\hline \multicolumn{2}{|l|}{ Location to get medicines } \\
\hline SUS only & $44(31.2)$ \\
\hline SUS and private network & $97(68.8)$ \\
\hline \multicolumn{2}{|l|}{ Self-medication } \\
\hline Yes & $82(58.2)$ \\
\hline No & $59(41.8)$ \\
\hline \multicolumn{2}{|c|}{ Knows the clinical pharmaceutical services } \\
\hline Yes & $47(33.3)$ \\
\hline No & $94(66.7)$ \\
\hline \multicolumn{2}{|c|}{ Interested in receiving clinical pharmaceutical services } \\
\hline Yes & $121(85.8)$ \\
\hline No & $20(14.2)$ \\
\hline
\end{tabular}

Figure 1 shows the amount of elderly patients recruited in each unit. Thirteen patients were interviewed at the São Francisco FHS, 16 at the Medianeira FHS, 19 at the Renovação FHS, 23 at the Santo Antônio FHS and 69 at the Central Pharmacy.

Figure 1. Sample distribution among the public pharmacies.

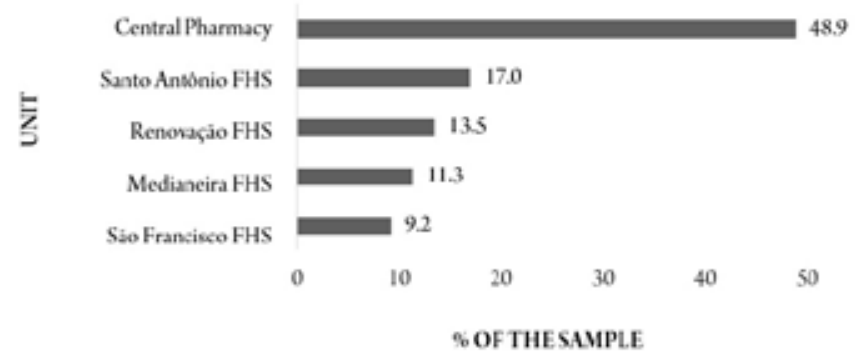

The self-reported health problems of the elderly are shown in Figure 2. In addition to these pathologies, $65.2 \%$ of the geriatric population cited the presence of other complications not described in the questionnaire.

Figure 2. Self-reported health problems by the elderly individuals interviewed.

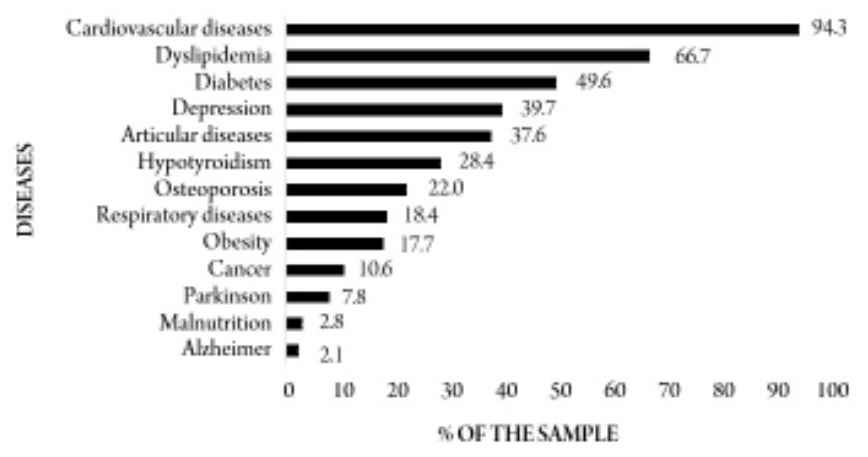

Regarding medications, 195 different presentations were cited. The average number was $7.8 \pm 2.2$ per elderly individual, 15 being the maximum consumed by a single patient. Figure 3 presents the 15 most prescribed medications and presentations.

Figure 3. Medications and presentations most used by the elderly.

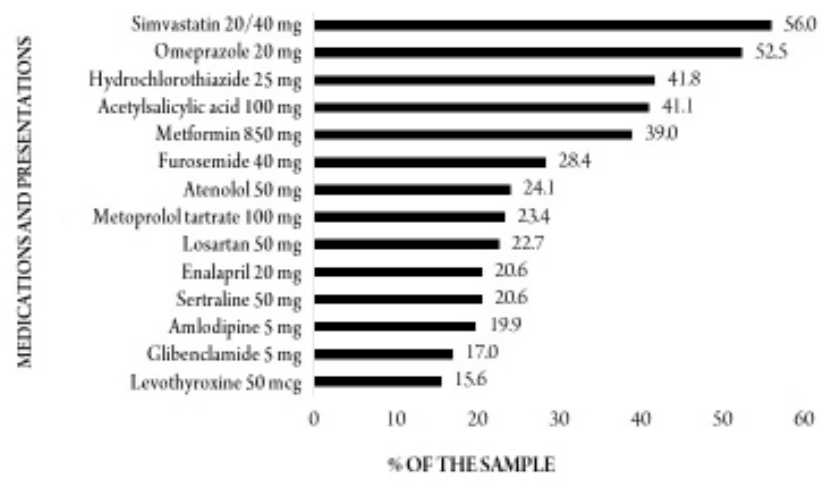

The BMQ result presented in Table 2 did not classify any of the elderly individuals as adherent. The variable "presence of the pharmacist" in the Central Pharmacy unit was not significantly associated $(\mathrm{p}<0.05)$ with adherence to the pharmacological treatment $(\mathrm{p}=0.833)$. There was also no statistical significance when crossing the "probable adherence" variable with the other sociodemographic variables. 
Table 2. BMQ-identified scores and adherence classification.

\begin{tabular}{lc}
\hline BMQVariables & $\mathbf{n}(\%)$ \\
\hline $\begin{array}{l}\text { Did R. fail to list (spontaneously) the prescription drugs? } \\
\text { Yes }\end{array}$ & $109(77.3)$ \\
No & $32(22.7)$ \\
Did R. discontinue therapy due to delayed dispensation or & \\
other reason? & \\
$\quad$ Yes & $29(20.6)$ \\
No & $112(79.4)$ \\
Did R. report any missed days or doses? & $60(42.6)$ \\
$\quad$ Yes & $81(57.4)$ \\
$\quad$ No & \\
Did R. reduce or omit doses of any medication? & $39(27.7)$ \\
Yes & $102(72.3)$ \\
No &
\end{tabular}

Did R. take any extra doses or medications more than prescribed? Yes No

Did R. answer that he "didn't know” to any of the questions? Yes No

Did R. refuse to answer some of the questions? Yes No

Did R. report “doesn't work well” or “don't know” in answer $\lg$ (how does this medication work for you)?

Yes

Did R. name the medicines that bother him?

Yes

No

Does R. receive a multiple dose regimen ( 2 or more)?

Yes

No

Does R. report "too much difficulty" or "any difficulty" in answering $3 \mathrm{c}$ (remember to take all the medication)? Yes

No

BMQclassification

Adherence

Probable adherence

Probable low adherence

Low adherence

R.: Respondent

\section{Discussion}

The sociodemographic data shown in Table 1 showed that the majority interviewed were female, which corroborates the findings of other epidemiological studies with the elderly $y^{2,10,11}$ demonstrating the feminization of old age.

Regarding age, the age group of $70-79$ years old (46.1\%) predominated. This profile differs from other publications evaluating the use of medications by the elderly where the mean age was lower. ${ }^{2.12}$ As already evidenced in population-based studies in the country, advanced age is one of the main risk factors for being a large drug user due to the high prevalence of CNCDs. ${ }^{2,13}$

The prevalent level of schooling reported in Table 1 does not differ from that observed in the elderly in general. This fact is also evidenced in other studies that considered polymedicated elderly, carried out in the capital cities of Florianópolis and São Paulo. ${ }^{11,14}$ It is worrisome to note that more than half of the participants had not completed elementary school, and low schooling can negatively influence the understanding and compliance with the prescription, which may lead to nonadherence to the treatment. ${ }^{11}$
The vast majority reported receiving approximately one minimum monthly salary, as in a study conducted in the SUS by Oliveira et al. ${ }^{12}$ This finding of lowincome elderly reinforces the main characteristics of the geriatric population served by the SUS and can serve as an indicator for solving social and health problems.

Self-medication was reported by $58.2 \%$ of the patients, a higher number than that found in the state capital of Goiás where more than $35.0 \%$ of the elderly practiced self-medication. ${ }^{10}$ Data from the latest National Survey on Access, Use and Promotion of Rational Use of Drugs (Pesquisa Nacional de Acesso, Utilização e Promoção do Uso Racional de Medicamentos, PNAUM) reported a percentage of $14.3 \%$ of self-medication in Brazil among individuals over 60 years old. ${ }^{15}$ Also according to the PNAUM, it was found that self-medication was associated with females, with age above 60 years old and with the prevalence of one or more chronic diseases, all dominant factors in the sample interviewed in Veranópolis.

In our study, the use of medicinal plants, including teas, as considered as self-medication. Furthermore, we know that in many of these works cited ${ }^{10,15}$ where the self-medication index was lower may have been omitted in the self-report.

Analgesics and anti-inflammatory drugs were the most cited drug classes. The use of analgesics and anti-inflammatory drugs through self-medication is common among the elderly due to pain and inflammation, common symptoms in this age group. Anti-inflammatory drugs should be administered with great caution in geriatrics. Their use is associated with a high risk of gastrointestinal toxicity and renal failure, and is related to cardiovascular events and numerous drug interactions. ${ }^{15,16}$

Self-medication is considered an element of self-care. However, in order to avoid complications to the individual and to the health system, especially in polymedicated elderly people who are more susceptible to irrational drug use, it is extremely important that their management be accompanied by information, ensuring a responsible self-medication. In this context, the guidance of the pharmacist, as a trained professional for counseling on medications, is fundamental and contributes to the rational use of medicines. ${ }^{15}$

Regarding access, all respondents used the SUS to obtain their pharmacotherapy, with $31.2 \%$ strictly using the public system to purchase their five or more drugs for continuous use. Among the respondents, there were no reports of difficulties in accessing medications included in the Municipal List of Essential Medicines (Relação Municipal de Medicamentos Essenciais, REMUME), such as lack or delays in dispensing, since the municipality has a well-structured pharmaceutical assistance in the technical-managerial aspect.

Regarding the data related to knowledge about pharmaceutical services, it is clear that, despite advances in pharmaceutical care, the pharmacist is still little known by the users of the SUS. The reality of the municipality reflects the Brazilian reality, where the number of working professionals is still insufficient to perform clinical activities

The lack of a significant association between the "pharmacist presence in the unit" variable and adherence to the drug treatment evidenced in this study may have the lack of direct pharmacist follow-up during dispensation as one of its root causes. The professional is involved in bureaucratic activities and is not available to accompany and serve the patients most of the time. A cross-sectional study, representative of the five regions of Brazil in primary care services, showed that only $6.0 \%$ of the pharmacists in the southern region reported performing any clinical activity in units. ${ }^{17}$

Baldoni et al. observed that only $5.0 \%$ of the patients treated in the SUS in the city of Ribeirão Preto (São Paulo), received guidance on the use of medications by the pharmacist. ${ }^{18}$

An exploratory study by Freitas et al. which investigated the main difficulties reported by the pharmacists for the exercise of the clinical activities highlighted that the managers, the health care staff and the society are still not convinced that pharmacists can solve the problems of health demanded by the system. ${ }^{19}$

This same study argues that an educational reform in the education of pharmacists, due to insufficient clinical training, is necessary for changes to occur. ${ }^{19}$

Acting pharmacists need to develop new skills and competencies for clinical work. This way, they can show their potential to the managers, to other health professionals and to the community. A successful example, which serves as a model for the Brazilian municipalities, has been the implementation of the pharmaceutical clinic services in Curitiba since 2013. This project has generated profound changes in the essence of the role of the pharmacist in primary care, positively impacting the health team and community, generating important indicators of the quality of medication use for managers. ${ }^{20}$

As shown in Table 1, the elderly expressed interest in receiving the services offered by the pharmacist after knowing the activities that can be developed. This data is relevant to the health system managers, for improving their goals and public policies in the municipal pharmaceutical care. 
From the presented scenario, the new Brazilian model and in line with the pharmacist's clinical attributions, we face a great challenge, but also a unique opportunity to recognize the relevance of the pharmacist's clinical performance in favor of the population's health., ${ }^{4,17,21}$

The main diseases reported in Figure 2 were similar to the findings by Nascimento and collaborators that characterized polymedicated users in primary care. $^{2}$ These are prevalent conditions in the country, especially in the elderly population, whose control and treatment require the use of drugs. ${ }^{22}$ There is then a certain consistency between the most commonly used drugs (Figure 3 ) and the reported diseases.

Among the most prescribed drugs, all belong to the basic component of pharmaceutical care, and sertraline is the only drug not listed in the National List of Essential Medicines (Relação Nacional de Medicamentos Essenciais, RENAME). However, it is included in the Special Component of Pharmaceutical Assistance of the state of Rio Grande do Sul and in the REMUME. With regard to the REMUME, the losartan drug is the only one not included in the municipal list. However, it is part of the Popular Pharmacy program and is provided in free pharmacies. Thus, free access to these medications is guaranteed upon presentation of the prescription.

As can be seen, the most prescribed drugs are primarily intended to treat cardiovascular conditions, dyslipidemia and diabetes. However, the two most commonly found drugs in the prescriptions, simvastatin and omeprazole, have been widely disputed by the scientific community regarding their use by the elderly. ${ }^{16}$ Therefore, the prescription of these drugs should be done cautiously. The prophylactic use of omeprazole, which might explain the high frequency of use in the study group, has been documented as irrational..$^{14,23}$ It demonstrates high potential for drug interactions making its use even more alarming in polymedicated elderly. ${ }^{22}$ The benefit-risk relation of statin use in the elderly has also been widely discussed in the new dyslipidemia guidelines, pointing out a lack of evidence of clinical benefit in this age group. ${ }^{24}$

In light of the above, there is a need for drug revision and potential deprescription for the purpose of minimizing harm and qualifying drug use. For this practice to become viable permanent training of the professionals is necessary, including the pharmacist. The possibility of setting up pharmaceutical follow-up services may be co-responsible for solving drug therapy adherence problems and, therefore, improve the clinical outcomes. ${ }^{22}$

In this study, we chose to analyze polymedicated elderly, because polypharmacy is considered an obstacle to treatment adherence. Therefore, the prevalence of low adherence and probable low adherence may be associated with several reasons, such as the selected critical work group, the use of five or more medications, and the prevalence of chronic diseases.

A study by Roy and collaborators using the BMQ in elderly patients showed that only $5.8 \%$ of the patients were adherent in the regimen domain. The complexity of the dosing schedule reported by $74.1 \%$ of the participants was the major barrier to adhesion. In this same study, $68.3 \%$ of the patients failed to name their medications. ${ }^{25}$ A number lower than that reported in Table 2, where $77.3 \%$ of the patients failed to name their medications.

As documented, the vast majority cannot spontaneously list the names of their medications or for which disease they are prescribed (Table 2). Medications are identified by color, size or packaging. Another fact reported by the patients was the importance of the information provided at the pharmacy counter of the units. Since the practice is to warn patients at the time of withdrawal if the drug has changed manufacturer and, consequently, packaging, size or color. This exchange is common in public agencies where purchases are usually made through a bidding process, a fact that can hinder adherence.

Another condition that may have provided this result was the type of questionnaire employed. The Brief Medication Questionnaire has greater sensitivity and specificity when compared to other validated questionnaires to verify treatment adherence. It considers a complex dosing schedule with two or more daily medications as strong evidence for probable low adherence. Therefore, in other studies that did not use this methodology, adherence may have been underestimated.

Among the limitations of the present study, we can mention the difficulty of applying the questionnaires to a larger number of patients since it was not possible to interview the initially estimated sample. The inclusion criteria did not allow including more respondents, as most of them did not use at least five drugs. Another factor that may have contributed was the way the sample size was calculated, based on the non-adherence rate. This non-adherence percentage considers all the chronic use treatments and not only patients on polypharmacy. The withdrawal of drugs by third parties and non-attendance of the patient in the unit also made this process difficult. In order to minimize a possible memory bias, the strategy used was the adoption of standardized procedures by the interviewers during data collection, such as requesting prescriptions or drug packaging. As a strong point of this work, we can highlight its usefulness to the managers of the health system of the municipality, in the improvement of its goals and policies in the pharmaceutical assistance, focused mainly on the elderly and the rational use of medicines.

\section{Conclusion}

It was possible to know the profile of medication use by the polymedicated elderly population who uses the SUS. From the data obtained the possibility arises of further discussions regarding the use of medications in the municipality. These results increase the knowledge about their use, highlighting the need for improving pharmaceutical care.

\section{Funding source}

Own funding with assistance from the Veranópolis Health Department.

\section{Authors' Contribution}

C Rigon was responsible for designing the study, applying the questionnaires, compiling data, evaluating the results and writing the article D Gnatta advised on data analysis and critical review of the article. Luvison and ECDT Kasmirscki participated in the data collection, assisting in the application of the questionnaires.

\section{Conflict of interests}

The authors declare no conflicts of interest.

\section{Acknowledgments}

To the Pharmacy Course of the Universidade de Caxias do Sul and to the Health Department of Veranópolis / RS.

\section{References}

1. World Health Organization. Active ageing: a policy framework. Madrid $\mathrm{WHO} ; 2002$

2. Ramos LR, Tavares NUL, Bertoldi AD et al. Polifarmácia e polimorbidade em idosos no Brasil: um desafio em saúde pública. Rev Saúde Pública 2016; $50(\operatorname{supl} 2): 9 \mathrm{~s}$

3. Araújo SQ, Costa KS, Luiza VL et al. Organização dos serviços farmacêuticos no Sistema Único de Saúde em regiões de saúde. Ciênc Saúde Coletiva 2017; 22(4): 1181-1191.

4. Conselho Federal de Farmácia. Resolução no 585 de 29 de agosto de 2013 Regulamenta as atribuições clínicas do farmacêutico e dá outras providências. Brasília: Conselho Federal de Farmácia; 2013.

5. Tavares NUL, Bertoldi AD, Mengue SS et al. Fatores associados à baixa adesão ao tratamento farmacológico de doenças crônicas no Brasil. Rev Saúde Pública 2016; 50(supl 2):10s.

6. Prefeitura Municipal de Veranópolis. Veranópolis; 2017. [Internet]. Disponível em: http://www.veranopolis.rs.gov.br Access in October 30 2017.

7. MoriguchiEH,editor.Certificação dos dados de Pesquisa do Projeto Veranópolis: Estudos em Envelhecimento, Longevidade e Qualidade de Vida. Veranópolis 2013. [Internet]. Disponível em: file:///C:/Users/User/ Downloads/projetoveranopolis-certificacao-final.pdf. Access in October 302017

8. Mendes EV. As redes de atenção à saúde. Brasília: Organização PanAmericana da Saúde; 2011.

9. Ben AJ, Neumann CR, Mengue SS. Teste de Morisky-Green e Brief Medication Questionnaire para avaliar adesão a medicamentos. Rev Saúde Pública 2012; 46(2): 279-289. 
10. Santos TRA, Lima DM, Nakatani AYK et al. Consumo de medicamentos por idosos, Goiânia, Brasil. Rev Saúde Pública 2013; 47(1): 94-103.

11. Pereira KG, Peres MA, Iop D et al. Polypharmacy among the elderly: a population-based study. Rev Bras Epidemiol 2017; 20(2): 335-344.

12. Oliveira REM, Nascimento MMG, Pereira ML. Uso de medicamentos por idosos de uma unidade de atenção primária à saúde. Rev Bras Farm Hosp Serv Saúde 2016; 7(3): 30-34

13. Bertoldi AD, Pizzol TSD, Ramos LR et al. Perfil sociodemográfico dos usuários de medicamentos no Brasil: resultados da PNAUM 2014. Rev Saúde Pública 2016; 50 (supl 2): 5s.

14. Carvalho MFC, Romano-Lieber NS, Bergsten-Mendes G et al. Polifarmácia entre idosos do Município de São Paulo - Estudo SABE. Rev Bras Epidemiol $2012 ; 15(4): 817-827$.

15. Arrais PSD, Fernandes MEP, Pizzol TSD et al. Prevalência da automedicação no Brasil e fatores associados. Rev Saúde Pública 2016; 50(supl 2): 13s

16. American Geriatrics Society. Updated Beers Criteria for Potentially Inappropriate Medication Use in Older Adults. J Am Geriatr Soc 2015; 63(11) 2227-2246.

17. Araújo PS, Costa EA, Guerra JAA et al. Pharmaceutical care in Brazil's primary health care. Rev Saúde Pública 2017; 51(supl 2): 6s.

18. Baldoni AO, Dewulf NLS, Santos V et al. Dificuldades de acesso aos serviços farmacêuticos pelos idosos. Rev Ciênc Farm Básica Apl 2014; 35(4): 615 621

19. Freitas GRM, Pinto RS, Luna-Leite MA et al. Principais dificuldades enfrentadas por farmacêuticos para exercerem suas atribuições clínicas no Brasil. Rev Bras Farm Hosp Serv Saúde 2016; 7(3): 35-41

20. Brazil Ministério da Saúde. Secretaria de Ciência, Tecnologia e Insumos Es tratégicos. Resultado do projeto de implantação do cuidado farmacêutico no município de Curitiba. Brasília: Ministério da Saúde; 2015.

21. Brazil Lei Federal no 13021 de 8 de agosto de 2014. Dispõe sobre o exercício e fiscalização das atividades farmacêuticas. Brasília: Diário Oficial da União; 2014.

22. Nascimento RCRM, Álvares J, Guerra JAA et al. Polypharmacy: a challenge for the primary health care of the Brazilian Unified Health System. Rev Saúde Pública 2017; 51(supl 2): 19s

23. Maes ML, Fixen DR, Linnebur SA. Adverse effects of proton-pump inhibitor use in older adults: a review of the evidence. Ther Adv Drug Saf 2017; 8(9) 273-297.

24. Aludi AA, Izar MCO, Saraiva JFK et al. Atualização da Diretriz Brasileira de Dislipidemias e Prevenção da Aterosclerose - 2017. Arq Bras Cardiol 2017; 109(2Supl.1): 1-76

25. Roy NT, Sajith M, Bansode MP. Assessment of factors associated with low adherence to pharmacotherapy in elderly patients. J Young Pharm 2017; $9(2): 272-276$ 